\title{
Pemberdayaan Perempuan dalam Peningkatan Kesehatan Reproduksi melalui Pemeriksaan Organ Reproduksi Mandiri
}

\author{
Farida Yuliani, Fitria Edni Wari, Erfiani Mail \\ E mail: farida_yuliani80@yahoo.co.id \\ STIKes Majapahit Mojokerto, Indonesia \\ J1. Raya Gayaman KM 02 Mojoanyar Mojokerto \\ Telp. 081236454098
}

\begin{abstract}
Abstrak
Kegiatan pengabdian kepada masyarakat ini memiliki tujuan untuk meningkatkan pemahaman masyarakat Desa Gayaman dan adanya perubahan perilaku mengenai deteksi dini kanker serviks dan kanker payudara. Metode yang digunakan dengan ceramah, diskusi, tanya jawab. Materi yang diberikan pada ibu usia subur adalah tentang deteksi dini kanker payudara dengan SADARI dan deteksi dini kanker serviks dengan pemeriksaan IVA. Kegiatan ini diikuti oleh 20 ibu usia subur di desa Gayaman Kecamatan Mojoanyar pada bulan Maret - Juni 2020. Hasil yang didapatkan yaitu peserta antusias dengan adanya pendidikan dan penyuluhan yang telah dilaksanakan didukung dengan hasil yang signifikan, dimana dari jumlah peserta $90 \%$ mamahami dan mampu mempraktekkan deteksi dini pemeriksaan SADARI. Hendaknya kegiatan ini dilaksanakan secara rutin dan kontinu agar para ibu usia subur dapat meningkatkan pengetahuan dan meningkatan cakupan pemeriksaan dini kanker serviks dan kanker payudara.
\end{abstract}

Kata Kunci: pemberdayaan; perempuan; pemeriksaan; mandiri.

\begin{abstract}
Community service activity aims to increase the understanding of the people of Gayaman Village and to change behavior regarding early detection of cervical cancer and breast cancer. The method used is health education, discussions, questions and answers. The material given to mothers of childbearing age is about early detection of breast cancer with BSE and early detection of cervical cancer by IVA examination. This activity was attended by 20 women of childbearing age in Gayaman Village, Mojoanyar District in March - June 2020. The results obtained were that the participants were enthusiastic about the education and counseling that had been carried out supported by significant results, where $90 \%$ of the participants understood and were able to practice early detection of BSE examination. This activity should be carried out regularly and continuously so that mothers of childbearing age can increase knowledge and increase the coverage of early screening for cervical cancer and breast cancer.
\end{abstract}

Keywords: empowering; women; examination; self.

\section{Pendahuluan}

Pemberdayaan perempuan berarti memberdayakan mereka dalam isu-isu fundamental kehidupan. Pemberdayaan

perempuan adalah dasar dari kependudukan dan program pembangunan Negara ${ }^{[1]}$. Kesehatan dan kesejahteraan saling berkaitan. Ketidakmampuan atau kurangnya pengendalian dalam hidup menjadi faktor risiko penyebab terjadinya beberapa penyakit, sementara kemampuan berpengaruh pada pengendalian kehidupan dan kesehatan. Dampak sosial dari pemberdayaan perempuan berpengaruh pada outcome kesehatan. Pemberdayaan perempuan dan partisipasi mereka secara 
signifikan berpengaruh terhadap kesehatan dan kualitas hidup masyarakat dan Keluarga. Wanita berdaya cenderung mengurus diri sendiri dan anak-anaknya ${ }^{[2]}$.

Masalah kesehatan reproduksi, terkait dengan terganggunya sistem, fungsi dan proses alat reproduksi yang dapat berakibat pada keharmonisan hubungan suami istri bahkan dapat mengganggu kelancaran proses kehamilan dan persalinan. Berbagai resiko dalam kesehatan reproduksi perempuan, seperti kanker payudara dan serviks [3].

Kanker merupakan salah satu penyakit tidak menular. Kanker serviks dan kanker payudara merupakan kanker yang paling tinggi prevalensinya di dunia maupun di Indonesia. Data Global Cancer Observatory 2018 dari WHO menunjukkan kasus kanker yang paling banyak terjadi di Indonesia yaitu kanker payudara sebesar 58.256 kasus atau $16,7 \%$ dari total 348.809 kaus kanker, selanjutnya kanker serviks sebanyak 32.469 kasus atau 9,3\% dari total kasus. Menurut Kementerian Kesehatan, angka kanker payudara di Indonesia mencapai 42,1 orang per 100 ribu penduduk. Rata-rata kematian akibat kanker ini mencapai 17 orang per 100 ribu penduduk. Sementara angka kanker serviks di Indonesia mencapai 23,4 orang per 100 ribu penduduk dengan rata-rata kematian mencapai 13,9 orang per 100 ribu penduduk ${ }^{[4]}$.

Peningkatan prevalensi kanker payudara dan serviks di negara berkembang dapat disebabkan akibat kurangnya program penapisan efektif yang bertujuan mendeteksi keadaan sebelum kanker maupun kanker pada stadium dini termasuk pengobatannya sebelum proses invasif yang lebih lanjut. Kematian kasus kedua kanker di negara berkembang juga diperparah dengan rendahnya kemampuan dan aksesibilitas untuk pengobatan.

Salah satu kunci keberhasilan pengendalian kedua kanker ini adalah penanggulangan terpadu meliputi penapisan (screening) yang dilanjutkan dengan pengobatan adekuat. Agar didapatkan hasil yang optimal, penapisan di fokuskan terhadap perempuan yang memiliki golongan umur tertentu sesuai target [5].

Upaya pengendalian kanker serviks di Indonesia dikembangkan upaya pencegahan melalui screening dengan metode IVA ( Inspeksi Visual dengan Asam Asetat) dan krioterapi untuk IVA positif. Sedangakan untuk kanker payudara screening melalui pemeriksaan payudara klinis (SADANIS) dan mengajarkan Periksa Payudara Sendiri (SADARI). Metode ini terbukti memberikan banyak keuntungan yaitu pemerisaan sederhana, mudah, murah, cepat, sensitifitas yang cukup baik ${ }^{[6]}$.

\section{Metode}

Kegiatan ini dilakukan secara bertahap yaitu survey lapangan, menentukan sasaran, melakukan koordinasi dengan perangkat desa setempat, melakukan sosialisasi program, melaksanakan program tersebut, dimana sasaran yang diundang adalah wanita usia subur yang ada di desa Gayaman.

Peserta diberikan materi tentang SADARI, pemeriksaan IVA, kemudian di akhir sesi peserta diberikan evaluasi serta demonstrasi tentang SADARI.

\section{Hasil dan Pembahasan}

Desa Gayaman terletak di perbatasan kota dan kabupaten Mojokerto dengan daerah yang sangat strategis, selain itu desa ini merupakan desa berdirinya STIKes 
Majapahit sehingga penulis sangat mudah dalam menjangkau area ini. Kegiatan ini secara garis besar menunjukkan hal yang menggembirakan yaitu $100 \%$ peserta merespon positif dalam hal kemanfatan yang sangat tinggi untuk menjalani masa tuanya dengan sehat dan bermanfaat. Ada beberapa hambatan dimana karena kegiatan dilakukan di balai desa Gayaman sehingga penulis tidak bias melakukan praktik secara langsung SADARI karena unsur privasi peserta sehingga penulis hanya melakukan demonstrasi pada phantom saja.

\section{Kesimpulan}

Pelaksanaan pengabdian masyarakat ini membawa dampak yang baik baik masyarakat khususnya wanita usia subur di Desa Gayaman. Pengetahuan tentang kanker serviks dan payudara serta cara melaksanakan deteksi dini secara mandiri seperti pemeriksaan SADARI menjadi lebih baik dan ibu usia subur menjadi termotivasi untuk melakukan pemeriksaan deteksi dini kanker serviks di pelayanan kesehatan terdekat.

\section{Daftar Pustaka}

[1] Kiani Z, Simbar M, Dolatian M, Zayeri F. Women's empowerment in reproductive decision-making needs attention among iranian women. Iran J Public Health, 47(3): 464-5, 2018.
[2] Varkey P, Kureshi S, Lesnick T. Empowerment of women and its association with the health of the community. $\mathrm{J}$ Women's Heal. 19(1):71-6, 2010.

[3] Palembang D. Dinkes Sosialisasi Kespro di 5 Ulu [Online].

https://dinkes.palembang.go.id /?nmodul=berita\&bhsnyo=id\& bid=168. 2011.

[4] Widowati H. Berbagai Kasus Kanker di Indonesia 2018. 2019. [Online]. https://databoks.katadata.co.id/ datapublish/2019/06/03/kasuskanker-payudara-palingbanyak-terjadi-diindonesia\#: : :text=Berbagai Kasus Kanker di Indonesia 2018\&text=Data Global Cancer Observatory 2018,dari total 348.809 kasus kanker.

[5] Widyasari N. Deteksi Dini Kanker Serviks dan Payudara Dinas Kesehatan Kabupaten Probolinggo. 2018 [Online]. http://p2ptm.kemkes.go.id/kegi atan-p2ptm/jawatimur/deteksi-dini-kankerserviks-dan-payudara-dinaskesehatan-kabupatenprobolinggo.

[6] Omeoo. Pelatihan Deteksi Dini Kanker Serviks dan Kanker Payudara. 2016 [Online] http://p2ptm.kemkes.go.id/kegi atan-p2ptm/pusat-/pelatihandeteksi-dini-kanker-serviksdan-kanker-payudara. 